\title{
PENGARUH KUALITAS JASA DAN KEPERCAYAAN TERHADAP LOYALITAS NASABAH PEGADAIAN (Studi Kasus Upc Sawah Lebar )
}

\author{
1); Ida Ayu Made Er Meytha Gayatri2); Eska Prima Monique Damarsiwi \\ 1,2 ) Department of Management, Faculty of Economic, Universitas Dehasen Bengkulu
}

Email: ${ }^{1)}$ Cinta.gayatri@yahoo.co.id ; ${ }^{2)}$ ds.monique@gmail.com

\author{
How to Cite : \\ Gayatri, Ida Ayu Made Er Meytha. et.al (2020). PENGARUH KUALITAS JASA DAN \\ KEPERCAYAAN TERHADAP LOYALITAS NASABAH PEGADAIAN (Studi Kasus Upc Sawah \\ Lebar ). EKOMBIS REVIEW: Jurnal IImiah Ekonomi Dan Bisnis, 9 (1). \\ DOI: https://doi.org/10.37676/ekombis.v9i1.1219
}

\section{ARTICLE HISTORY}

Received [2 November 2020]

Revised [12 December 2020]

Accepted [12 January 2021]

\section{KEYWORDS}

Service quality, trust, loyalty costumer

This is an open access article under the $C C-B Y-S A$ license

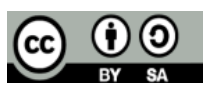

\section{ABSTRAK}

Penelitian ini bertujuan untuk mengetahui sejauh mana pengaruh kualitas jasa dan kepercayaan terhadap loyalitas nasabah di Pegadaian Kota Bengkulu Upc Sawah Lebar. Jenis penelitian ini adalah penelitian kuantitatif dimana pengambilan sampel menggunakan teknik sampling incidental dan jumlah sampel sebanyak 30 responden. Teknik pengumpulan data menggunakan kuesioner. Data yang diperoleh dianalisis menggunakan SPSS, dengan uji analisis regresi berganda, kolerasi ganda dan uji statistik (uji t, dan uji $F_{\text {, }}$ ).

Hasil dari penelitian menunjukkan bahwa secara simultan, variabel kualitas jasa dan kepercayaan, secara bersama-sama mempengaruhi loyalitas nasabah di pegadaian Upc Sawah Lebar. Sedangkan secara parsial variabel kualitas jasa (X1) berpengaruh signifikan terhadap loyalitas nasabah di Pegadaian Upc Sawah Lebar dengan nilai sig 0,012. Variabel kepercayaan (X2) juga berpengaruh signifikan terhadap loyalitas nasabah di Pegadaian Upc Sawah Lebar dengan nilai sig 0,21. Sedangkan koefisien determinasi $\left(R^{2}\right)$ sebesar 52,1 untuk Upc Sawah Lebar ini artinya bahwa kontribusi variabel independen menjelaskan atau mempengaruhi variabel dependen sebesar $52,1 \%$, sedangkan sisanya $47,9 \%$ dipengaruhi oleh variabel yang lainnya yang tidak di teliti dalam penelitian ini.

\section{ABSTRACT}

This type of research is a quantitative study in which sampling uses incidental sampling techniques and the number of samples 30 respondents. The technique of answering data using a questionnaire. The data obtained were analyzed using SPSS, with analysis test multiple regression, double correlation analysis and statistical tests ( $\mathrm{t}$ test, and $\mathrm{F}$ test, ). The results of 
the study indicate that simultaneously, service quality and trust variables, together affect loyalty in Upc Sawah Lebar. While partially the service quality variable (X1) significantly influences customer loyalty at Upc Sawah Lebar with a sig value of 0.012 . The trust variable (X2) also has a significant effect on customer loyalty at Pegadaian Upc Sawah Lebar with a sig value of 0.21. While the coefficient of determination (R2) of 52.1 for Upc Sawah Lebar means that the contribution of an independent variable explains or influences the dependent variable by $52.1 \%$, while the remaining $47.9 \%$ is influenced by other variables not examined in this study.

\section{PENDAHULUAN}

Loyalitas pelanggan merupakan salah satu strategi perusahaan untuk mempertahankan bisnis dan profit perusahaan. Imbalan dari loyalitas sendiri bersifat jangka panjang dan kumulatif, jadi semakin lama seorang pelanggan loyal terhadap suatu produk/jasa, semakin besar laba yang diperoleh perusahaan dari seorang calon pelanggan (Griffin dalam Sinaga, 2010). Kualitas jasa sering didefinisikan sebagai usaha pemenuhan dari keinginan pelanggan serta ketepatan penyampaian jasa dalam rangka memenuhi harapan pelanggan. Menurut Wyckof dalam Tjiptono (2005) berpendapat bahwa Kualitas jasa merupakan tingkat keunggulan (exellence) yang diharapkan dalam pengendalian atas keunggulan tersebut untuk memenuhi keinginan pelanggan. Selain kualitas jasa, kepercayaan juga merupakan salah satu faktor yang mempengaruhi loyalitas pelanggan.Menciptakan kepercayaan bagi konsumen adalah hal yang penting, mengingat salah satu alasan konsumen menjadi pelanggan yang loyal adalah berdasarkan kepercayaan konsumen terhadap suatu perusahaan.Pada dasarnya kepercayaan pelanggan adalah harapan yang dipegang konsumen bahwa suatu perusahaan dapat diandalkan dalam memenuhi kebutuhan konsumen.

Perusahaan pegadaian merupakan lembaga keuangan yang menyediakan fasilitas pinjaman dengan jaminan tertentu. Jaminan nasabah tersebut di gadaikan dan kemudian di taksir oleh pihak pegadaian untuk menilai besarnya nilai jaminan. Pegadaian merupakan salah satu alternatif pendanaan yang sangat efektif karena tidak memerlukan persyaratan yang rumit atau yang dapat menyulitkan nasabah untuk memperoleh dana pinjaman, cukup membawa barang jaminan dan kartu identitas masyarakat sudah bisa mendapatkan dana untuk kebutuhan nya, di samping itu proses pencairan dana terbilang cepat dan mudah. Penelitian ini dilakukan di Upc Sawah Lebar, karena walaupun upc adalah Unit Pembantu Cabang, Upc juga perlu meningkatkan kualitas nya maka yang perlu di perhatikan dalam meningkatkan kualitas yakni kuitas jasa yang di berikan, kepercayaan konsumen dan loyalitas nasabah.

\section{Kualitas Jasa}

\section{LANDASAN TEORI}

Lovelock dalam Juni (2017:51) menyatakan bahwa kualitas jasa adalah tingkat keunggulan yang di harapakan dan pengendalian atas tingkat keunggulan dan tersebut untuk memenuhi keinginan konsumen. Menurut Tjiptono (2000) stretegi kualitas jasa atau layanan mencakup empat hal berikut:

1. Atribut layanan pelanggan

30 I Ida Ayu Made Er M. G.; Eska P. M. D.; Pengaruh Kualitas Jasa dan Kepercayaan... 
Adalah penyampaian layanan atau jasa harus tepat waktu, akurat, dengan perhatian dan keramahan.

2. Pendekatan untuk penyempurnaan kualitas jasa

Merupakan aspek penting dalam rangka menciptakan kepuasan pelanggan. Faktor biaya, waktu menerapkan program, dan pengaruh layanan pelanggan. Ketiga faktor ini merupakan inti pemahaman dan penerapan suatu sistem yang responsive terhadap pelanggan dan organisasi untuk pencapaian kepuasan optimum.

3. Sistem umpan balik untuk kualitas layanan pelanggan

Umpan balik sangat dibutuhkan untuk evaluasi dan perbaikan berkesinambungan. Informasi umpan balik harus difokuskan pada hal-hal berikut: memahami persepsi pelanggan terhadap perusahaan, jasa perusahaan dan para pesaing; mengukur dan memperbaiki kinerja perusahaan; mengubah bidang-bidang terkuat perusahaan menjadi faktor pembeda pasar; mengubah kelemahan menjadi peluang berkembang, sebelum pesaing lain melakukannya; mengembangkan sarana komunikasi internal agar setiap orang tahu apa yang mereka lakukan; dan menunjukkan komitmen perusahaan pada kualitas dan para pelanggan.

4. Implementasi

Sebagai bagian dari proses implementasi, manajemen harus menentukan cakupan kualitas jasa dan tingkat layanan pelanggan sebagai bagian dari kebijakan organisasi.

Dalam meningkatkan kualitas jasa, banyak faktor yang perlu dipertimbangkan dan upaya tersebut juga berdampak luas terhadap budaya organisasi secara keseluruhan. Faktor-faktor yang perlu mendapat perhatian yaitu (Tjiptono, 2000):

1. Mengidentifikasi determinan utama kualitas jasa.

2. Mengelola harapan pelanggan.

3. Mengelola bukti kualitas jasa yang bertujuan untuk memperkuat persepsi pelanggan selama dan sesudah jasa diberikan.

4. Mendidik konsumen tentang jasa (membantu pelanggan dalam memahami suatu jasa).

5. Mengembangkan budaya kualitas.

6. Menciptakan Automating Quality.

7. Menindaklanjuti jasa dalam membantu memisahkan aspek-aspek jasa yang perlu ditingkatkan.

8. Mengembangkan Sistem Informasi Kualitas Jasa.

\section{Kepercayaan}

Mowen dan Minor (2002) kepercayaan konsumen adalah semua pengetahuan yang dimiliki oleh konsumen dan semua kesimpulan yang dibuat konsumen tentang objek, atribut, dan manfaatnya. Objek dapat berupa produk, orang, perusahaan, dan segala sesuatu dimana seseorang memiliki kepercayaan dan sikap. Kennedy (2002) kepercayaan pelanggan di ukur melalui empat indikator yaitu: Dependabiity, honest, competence, and likable. Dependability yaitu pelanggan menggantungkan harapan dan kepercayaannya pada janji di sampaikan perusahaan melalui pesan iklan dan personal selling kepada pelanggan. Honesty Kejujuran yang melekat pada personil perusahaan. Kejujuran dalm kontek perusahaan adalah kejujuran yang melekat pada manusiannya dalam memberikan informasi dan layanan yang dibutuhkan pelanggan. Kejujuran personil (manusia) perusahaan dari sudut pandang pelanggan sangat penting karena pelanggan mempercayai perusahaan karena manusia yang bekerja di dalamnya jujur 
dan transparan dalam melayani dan memberikan informasi yang di butuhkan. Competence yaitu "kompetensi perusahaan dan kompetensi sales person. Pembahasan awal adalah kompetensi perusahaan yang menjadi ke unggulan bersaing perusahaan di banding perusahaan pesaing. Misalnya profesionalisme staf, desain barang/jasa, citra rasa dari suatu produk, layanan unggul dan keunggulan teknologi. Likable yaitu sifat personil perusahaan dan sales person yang menyenangkan para pelanggan. Pelanggan menyenangi staf perusahaan karena sopanberbicara, ramah, berbusana rapih dan sifat suka membantu memecahkan masalah atau komplain pelanggan yang berkaitan dengan produk/jasa yang telah di beli. tertentu terhadap yang lain dalam melakukan hubungan transaksi berdasarkan suatu keyakinan bahwa orang yang dipercayaainya tersebut memiliki keawjibannya sesuai yang diharapkan. Mowen dalam Juni (2017) menyatakan bahwa kepercayaan adalah semua pengetahuan yang dimiliki oleh konsumen dan semua kesimpulan yang dibuat oleh konsumen tentang objek, atribut, dan manfaatnya. Peppers dalam Juni (2017) menyatakan bahwa kepercayaan adalah keyakinan satu pihak pada reliabilitas, durabilitas, dan integritas pihak lain dalam relationship dan keyakinan bahwa tindakan nya merupakan kepentingan yang paling baik dan akan menghasilkan hasil positif bagi pihak yang di percaya. Kepercayaan merupakan hal penting bagi kesuksesan relationship. Kepercayaan harus menimbukan perilaku loyalitas konsumen sehingga terus menerus melakukan pembelian ulang.

Mukherjee dalam Juni (2017:123) menyatakan bahwa kepercayaan dapat di ukur melalui :

1. Sistem Yang Di Gunakan ( System Orientation)

Besarnya kepercayaan konsumen terhadap suatu perusahaan dan produl atau jasa yang dijual berkaitan dengan besar nya kepercayaan mereka terhadap sistem yang di gunakan perusahaan tersebut. Ketika konsumen memeperkiraakan faktor kepercayaan, beberapa persoalan muncul dalam fikiran mereka dan salah satu persoalan tersebut adalah kesesuain kemampuan dari sistem tersebut dengan harapan konsumen. Konsumen menggunakan beberapa ukuran seperti kecepatan, keakuratan, kemampuan mengatasi masalah dan ketahanan terhadap situasi tertentu.

2. Reputasi (reputation)

Reputasi dapat diartikan sebagai 'keseluruhan kualitas atau karakter yang dapat dilihat atau di nilai secara umum oleh masyarakat". Ketika konsumen bermaksud melakukan transaksi dengan suatu perusahaan, mereka akan mempertimbangkan reputasi perusahaan tersebut di mana konsumen merasa suatu perusahaan memiliki reputasi yang jelek, mereka akan malas menggunakan jasa atu produk perusahaan tersebut.

3. Resiko yang di presepsikan (perceived risk)

Besarnya persepsi konsumen mengenai risiko mempengaruhi kepercayaan mereka terhadap perusahaan/pemasar tersebut sehingga ketika hendak menggunakan produk atau jasa perusahaan tersebutm konsumen menganggap bahwa ada risiko yang tinggi. Konsumen yang mempunyai pengalaman tentu akan mempunyai lebih banyak informasi mengenai perusahaan dan produk atau jasa yang di jual nya sehingga mereka beranggapan risiko nya lebih rendah dank arena itu mereka mempunyai kepercayaan yang lebih tinggi pada perusahaan tersebut.

\section{Loyalitas Nasabah}

Loyalitas nasabah dapat didefenisikan sebagai komitmen nasabah terhadap suatu merk berdasarkan sikap yang sangat positif dan tercermin dalm pembelian ulang

32 I Ida Ayu Made Er M. G.; Eska P. M. D.; Pengaruh Kualitas Jasa dan Kepercayaan... 
yang konsisten. Defenisi tersebut mencakup dua komponen penting, yaitu loyalitas sebagai perilaku dan loyalitas sebagai sikap.

Loyalitas merupakan sebuah prilaku dimana pengalaman pembelian produk yang dijadikan acuannya atau menjadi tolak ukurnya. Loyalty (loyalitas) adalah komitmen yang mendalam untuk melakukan pembelian ulang suatu produk atau jasa yang disukai secara konsisten di waktu yang akan datang. Definisi loyalitas menurut Kotler dan Keller (2012) komitmen yang dipegang secara mendalam untuk membeli atau mendukung kembali produk atau jasa yang disukai di masa depan meski pengaruh situasi dan usaha pemasaran berpotensi menyebabkan pelanggan beralih. Griffin (2012) menyatakan bahwa karakteristik pelanggan yang loyal antara lain melakukan pembelian berulang secara teratur, membeli antar lini produk dan jasa, menunjukkan kekebalan terhadap tarikan dari pesaing serta mereferensikan kepada orang lain.

Tjiptono (2005) mengemukakan enam indikator yang bisa digunakan untuk mengukur loyalitas konsumen yaitu:

1) Pembelian ulang.

2) Kebiasaan mengkonsumsi merek tersebut.

3) Selalu menyukai merek tersebut.

4) Tetap memilih merek tersebut.

5) Yakin bahwa merek tersebut yang terbaik.

6) Merekomendasikan merek tersebut pada orang lain

\section{KERANGKA ANALISIS}

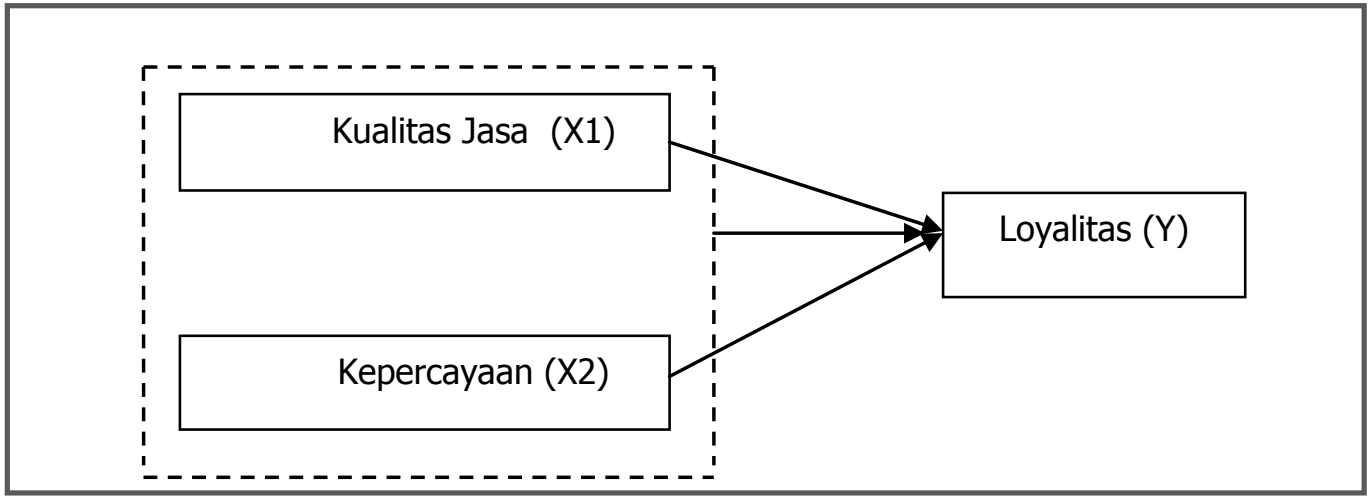

Gambar 1. Kerangka Analisis

Kerangka analisis di atas menjelaskan bahwa kualitas jasa (X1) dan Kepercayaan (X2) merupakan faktor yang berkaitan dengan loyalitas nasabah (Y).

\section{METODE PENELITIAN}

\section{Metode Analisis}

Metode yang digunakan dalam penelitian ini adalah sebagai berikut :

a. Analisis Regresi Berganda

Karena dalam penelitian ini terdapat lebih dari satu variabel bebas yang akan diuji untuk mengetahui pengaruhnya terhadap variabel terikat, maka proses analisis regresi yang dilakukan adalah menggunakan analisis regresi berganda. Menurut 
Sugiyono (2013) mendefinisikan bahwa:"Analisis regresi ganda digunakan oleh peneliti, bila peneliti bermaksud meramalkan bagaimana keadaan (naik turunnya) variabel dependen (kriterium), bila dua atau lebih variabel independen sebagai faktor prediktor dimanipulasinya (dinaik-turunkannya)". Persamaan regresi berganda untuk dua prediktor yang ditetapkan adalah sebagai berikut:

$$
\begin{aligned}
& Y=a+b_{1} X_{1}+b_{2} X_{2} \\
& \text { Keterangan: } \\
& Y=\text { Kepuasan nasabah } \\
& a=\text { Koefesien konstanta } \\
& \mathrm{b}_{1} \mathrm{X}_{1}=\text { kualitas jasa } \\
& \mathrm{b}_{2} \mathrm{X}_{2}=\text { kepercayaan }
\end{aligned}
$$

b. Analisis Korelasi Ganda

Analisis kolerasi ganda didasari atas pengaruh satu variabel independen dengan satu variabel dependen. Menurut Sugiyono (2009), Apabila analisis korelasi ganda sederhana didasari atas hubungan fungsional atau kausal satu variabel independen dengan satu variabel dependen, maka analisis korelasi ganda didasari atas hubungan fungsional atau kausal dua atau lebih variabel independen dengan satu variabel dependen. Pada penelitian ini ada dua variabel bebas sehingga menurut Sugiyono (2009) persamaan korelasi ganda tersebut adalah :

$$
R_{y x 1, x 2}=\sqrt{\frac{r_{y x 1}^{2}+r_{y x 2_{1}}^{2}-2 r_{y x 1} r_{y x 2} r_{x 1 x 2}}{1-r_{x 1 x 2}}}
$$

c.

$R_{y x 1, x 2}=$ Korelasi antara variabel $\mathrm{X}_{1}$ dan $\mathrm{X}_{2}$ secara bersama-sama dengan variabel $Y$

$r_{y x 1}=$ Korelasi antara variabel $\mathrm{X}_{1}$ dengan variabel $\mathrm{Y}$

$r_{y x 2}=$ Korelasi antara variabel $\mathrm{X}_{2}$ dengan variabel $\mathrm{Y}$

$r_{x 1 x_{2}}=$ Korelasi antara variabel $\mathrm{X}_{1}$ dengan variabel $\mathrm{X}_{2}$

Tabel 1. Pedoman untuk memberikan interprestasi koefisien korelasi

\begin{tabular}{|c|c|}
\hline Interval Koefisien & Tingkat hubungan \\
\hline $0,00-0,199$ & Sangat rendah \\
\hline $0,20-0,399$ & Rendah \\
\hline $0,40-0,599$ & Sedang \\
\hline $0,60-0,799$ & Kuat \\
\hline $0,80-1,000$ & Sangat kuat \\
\hline
\end{tabular}

Sumber: Sugiyono (2013)

c. Uji T

Uji t dilakukan untuk menguji hipotesis parsial (sendiri-sendiri) antara variabel kualitas jasa dan kepercayaan terhadap loyalitas nasabah. Kriteria pengujiannya adalah:

a. Jika probabilitas (sig) < alpha 0,05 maka Ha diterima dan Ho ditolak, yang berarti bahwa variabel kualitas jasa dan kepercayaan berpengaruh signifikan terhadap loyalitas nasabah

34 I Ida Ayu Made Er M. G.; Eska P. M. D.; Pengaruh Kualitas Jasa dan Kepercayaan... 
b. Jika probabilitas (sig) > alpha 0,05 maka Ha ditolak dan Ho diterima, yang berarti bahwa variabel kualitas jasa dan kepercayaan tidak

d. Uji $F$ berpengaruh signifikan terhadap loyalitas nasabah

Uji F dilakukan untuk menguji hipotesis secara simultan (bersama-sama) antara variabel kualitas jasa dan kepercayaan terhadap loyalitas nasabah. Kriteria pengujiannya adalah:

a. Jika probabilitas (sig) < alpha 0,05 maka Ha diterima dan Ho ditolak, yang berarti bahwa secara bersama-sama (simultan) variabel kualitas jasa dan kepercayaan berpengaruh signifikan terhadap loyalitas nasabah

b. Jika probabilitas (sig) > alpha 0,05 maka Ha ditolak dan Ho diterima, yang berarti bahwa secara bersama-sama (simultan) variabel kualitas jasa dan kepercayaan tidak berpengaruh signifikan terhadap loyalitas nasabah

HASIL

\section{HASIL DAN PEMBAHASAN}

1. Analisis regresi berganda

Karena dalam penelitian ini terdapat lebih dari satu variabel bebas yang akan diuji untuk mengetahui pengaruhnya terhadap variabel terikat, maka proses analisis regresi yang dilakukan adalah menggunakan analisis regresi berganda. Berdasarkan hasil dari perhitungan spss di peroleh nilai

$$
\begin{aligned}
& a=15,172 \\
& b_{1}=0,304 \\
& b_{2}=0,339
\end{aligned}
$$

dan dapat diperoleh persamaan regresi linear berganda antara Kualitas Jasa dan Kepercayaan dengan Kepuasan Nasabah, yaitu:

$$
\begin{aligned}
& Y=15,172+0,304 X_{1}+0,339 X_{2} \\
& \text { Dimana : } \\
& Y=\text { Kepuasan Nasabah } \\
& a=\text { Koefesien konstanta } \\
& X_{1}=\text { Kualitas Jasa } \\
& X_{2}=\text { Kepercayaan }
\end{aligned}
$$

Dari persamaan diatas dapat dikerahui bahwa :

1. Nilai Konstanta sebesar 15,172 artinya jika tidak terjadi perubahan variabel kualitas jasa dan kepercayaan nilai $\left(X_{1}\right.$ dan $X_{1}$ adalah 0$)$ maka loyalitas nasabah adalah sebesar 15,172 .

2. Nilai koefisien regresi kualitas jasa $\left(X_{1}\right)$ adalah 0,304 artinya jika variabel kualitas jasa meningkat sebesar $1 \%$ dengan asumsi variabel kepercayaan $\left(\mathrm{X}_{1}\right)$ dan konstanta (a) adalah 0 maka loyalitas nasabah ( $\mathrm{Y}$ ) meningkat sebesar $30,4 \%$ hal tersebut menunjukan bahwa variabel kualitas jasa $\left(X_{1}\right)$ berkontribusi positif bagi loyalitas nasabah sehingga makin baik kualitas jasa yang di berikan maka makin naik pula tingkat loyalitas nasabah.

3. Nilai koefisien regresi variabel kepercayaan $\left(X_{2}\right)$ adalah 0,339 artinya jika variabel kepercayaan meningkat sebesar $1 \%$ dengan asumsi variabel kualitas jasa $\left(\mathrm{X}_{1}\right)$ dan konstanta (a) adalah 0 maka loyalitas nasabah $(\mathrm{Y})$ meningkat sebesar $3,39 \%$ hal tersebut menunjukan bahwa variabel kepercayaan $\left(X_{1}\right)$ 
berkontribusi positif bagi loyalitas nasabah sehingga makin baik kualitas jasa yang di berikan maka makin naik pula tingkat loyalitas nasabah.

\section{Analisis Korelasi ganda}

Nilai Korelasi $(R)$ antara Kualitas Jasa $\left(X_{1}\right)$ dan Kepercayaan $\left(X_{2}\right)$ dengan Loyalitas Nasabah ( $Y$ ) adalah 0,722 atau $72,2 \%$ sedangkan sisa nya $27,8 \%$ tidak mampu menjelaskan variabel variabel lainya yang bisa menjelaskan variabel $Y$. Karena nilai 0,722 berada antara 0,60-0,799 maka hubungan tersebut dikatakan kategori kuat. Nilai Koefisien Determinasi $\left(\mathrm{R}\right.$ Square $=\mathrm{R}^{2}$ ) antara Kualitas Jasa $\left(\mathrm{X}_{1}\right)$ dan Kepercayaan $\left(X_{2}\right)$ dengan Loyalias Nasabah $(Y)$ adalah 0,521. Artinya kontribusi variabel Kualitas Jasa $\left(\mathrm{X}_{1}\right)$ dan Kepercayaan $\left(\mathrm{X}_{2}\right)$ dalam mempengaruhi Loyalitas Nasabah $(\mathrm{Y})$ sebesar $52,1 \%$, sementara $47,9 \%$ dipengaruhi oleh variabel lain yang tidak diteliti pada penelitian ini.

3. Uji t

Untuk mengetahui pengaruh masing-masing variable independent (Kaulitas Jasa dan Kepercayaan) terhadap variabel dependent (Loyalitas Nasabah) dilakukan dengan menggunakan Uji $\mathrm{t}$, di dapat nilai $\mathrm{X}_{1}$ dan $\mathrm{X}_{2}$ adalah sebagai berikut :

Kualitas jasa $\left(X_{1}\right)$ nilai $t=2,693$ dengan nilai signifikansi 0,012

Kepercayaan $\left(X_{2}\right)$ nilai $t=2,444$ dengan nilai signifikansi 0,012

Dari pernyataan diatas maka dapat di ketahui :

1. Pengaruh Kualitas Jasa terhadap Loyalitas Nasabah

Diperoleh nilai $t=2,693$ dengan nilai sig $=0,012$. Berarti nilai $t_{\text {hitung }} 2,693>t_{\text {tabel }}$ 2,051 dan nilai sig 0,012 < 0,05 maka secara statistik dapat dikatakan bahwa ada pengaruh yang signifikan antara Kualitas Jasa dengan Loyalitas Nasabah Pegadaian di UPC Sawah Lebar Kota Bengkulu.

2. Pengaruh Kepercayaa terhadap Kepuasan Nasabah

Diperoleh nilai $t=2,444$ dengan nilai sig $=0,021$. Berarti nilai $t_{\text {hitung }} 2,444>t_{\text {tabel }}$ 2,051 nilai sig 0,021 < 0,05 maka secara statistik dapat dikatakan bahwa ada pengaruh yang signifikan antara Kepercayaan dengan Loyalitas Nasabah Pegadaian di UPC Sawah Lebar Kota Bengkulu.

4. Uji $F$

Dengan melihat nilai $\mathrm{f}_{\text {tabel }}$ untuk probabilita 0,05 yakni dengan rumus $\mathrm{db} 1=\mathrm{k}$ 1 dan $\mathrm{db} 2=\mathrm{n}-\mathrm{k}$

Dimana :

$\mathrm{db}=$ derajat bebas

$\mathrm{k}=$ jumlah variabel penelitian (independen + dependen)

$\mathrm{n}=$ jumlah responden

$\mathrm{db} 1=3-1=2$

$\mathrm{db} 2=30-3=27$

maka nilai $\mathrm{f}_{\text {tabel }}$ di dapatkan db1 (pembilang) adalah 2 dan db2 penyebut adalah 27 dan jatuh pada koordinat 3,35 dengan tingkat kesalahan $5 \%$ jadi $f_{\text {tabel }}$ nya adalah 3,35

Dari uji ANOVA atau $F$ test, didapat nilai $f_{\text {hitung }}$ adalah 14,670 ftabel nya 3,35 sehingga nilai $f_{\text {hitung }}>f_{\text {tabel }}$ atau $14,670>3,35$ dan tingkat signifikan 0,000<0,05 maka Ho dengan kata lain ada pengaruh secara bersama-sama (simultan) antara

36 I Ida Ayu Made Er M. G.; Eska P. M. D.; Pengaruh Kualitas Jasa dan Kepercayaan... 
Kualitas Jasa dan Kepercayaan dengan Loyalitas Nasabah Pegadaian di Upc Sawah Lebar Kota Bengkulu.

\section{PEMBAHASAN}

1. Pengaruh Kualitas Jasa Terhadap Loyalitas Nasabah Pegadaian UPC Sawah Lebar

Berdasarkan hasil penelitian diketahui bahwa kualitas jasa berpengaruh positif terhadap dan signifikan terhadap loyalitas nasabah Pegadaian UPC Sawah Lebar dengan mkooefisien nilai regresi sebesar 0,304 dan nilai probabilitas (sig) 0,012 < alpha 0,05 termasuk pada kriteria pengujian $\mathrm{Ha}$ diterima dan Ho ditolak. Hal ini mennjukkan bahwa jika semakin baik kualitas jasa maka nasabah Pegadaian UPC Sawah Lebar akan semakin loyal. Hasil penelitian ini didukung oleh penelitian Syafira Ulfa et al (2018) yang membuktikan bahwa nilai yang dirasakan berpengaruh positif dan signifikan terhadap loyalitas pelanggan.

Apabila jasa yang di terima atau di rasakan lebih menyenangkan di banding harapannya, maka akan menimbulkan kepuasan, sebaliknya apabila jasa yang di terima atau di rasakan kurang dari harapan, maka di katakana bahwa kualitas layanan jelek. Kualitas mempunyai hubungan yang erat sekali dengan konsumen. Kualitas memberikan suatu dorongan kepada konsumen untuk menjalin ikatan hubungan yang kuat dengan perusahaan untuk memahami dengan seksama harapan konsumen.

2. Pengaruh Kepercayaan Terhadap Loyalitas Nasabah Pegadaian UPC Sawah Lebar

Berdasarkan hasil penelitian diketahui bahwa kepercayaan berpengaruh positif dan signifikan terhadap loyalitas nasabah Pegadaian UPC Sawah Lebar dengan koefisien nilai regresi sebesar 0,339 dan nilai probabilitas (sig) 0,021 < alpha 0,05 termasuk pada kriteria pengujian $\mathrm{Ha}$ diterima dan Ho ditolak. Hal ini menunjukkan bahwa jika semakin baik kepercayaan maka nasabah Pegadaian UPC Sawah Lebar akan semakin loyal. Hasil penelitian ini sejalan dengan hasil penelitian Rizal et al (2019) yang membuktikan kepercayaan berpengaruh positif dan signifikan terhadap loyalitas pelanggan.

Rofiq dalam Juni (2017) menyatakan bahwa keprcayaan (trust) adalah keprcayaan pihak tertentu terhadap yang lain dalam melakukan hubungan transaksi berdasarkan suatu keyakinan bahwa orang yang dipercayaainya tersebut memiliki keawjibannya sesuai yang diharapkan.

Mowen dalam Juni (2017) menyatakan bahwa kepercayaan adalah semua pengetahuan yang dimiliki oleh konsumen dan semua kesimpulan yang dibuat oleh konsumen tentang objek, atribut, dan manfaatnya. Peppers dalam Juni (2017) menyatakan bahwa kepercayaan adalah keyakinan satu pihak pada reliabilitas, durabilitas, dan integritas pihak lain dalam relationship dan keyakinan bahwa tindakan nya merupakan kepentingan yang paling baik dan akan menghasilkan hasil positif bagi pihak yang di percaya. Kepercayaan merupakan hal penting bagi kesuksesan relationship.

\section{KESIMPULAN}

\section{KESIMPULAN DAN SARAN}

Berdasarkan hasil penelitian yang telah dilakukan, maka dapat diambil kesimpulan sebagai berikut :

1. Dari hasil analisis regresi berganda yang dilakukan maka dapat diperoleh persamaan linear berganda yakni : $Y=15,172+0,304 X_{1}+0,339 X_{2}$ 
Dengan konstanta regresi sebesar 15,172 artinya bahwa ketika tidak ada variabel kualitas jasa dan kepercayaan maka loyalitas nasabah sebesar 15,172

2. Nilai kolerasi antara kualitas jasa dan kepercayaan untuk Upc Sawah Lebar yakni 0,722 yang berada di antara nilai 0,60-0,799 yang dikategorikan kuat dan nilai koefisien determinasi 0,0521 artinya kontribusi kualitas jasa dan kepercayaan sebesar $52,1 \%$ sementara $47,9 \%$ di pengaruhi oleh variabel lain yang tidak di teliti pada penelitian ini.

3. Uji t kualitas jasa $\left(X_{1}\right)$ diperoleh nilai $t$ untuk kualitas jasa adalah $t_{\text {hitung }} 2,693>t_{\text {tabel }}$ 2,051 dengan nilai sig= 0,012 yang artinya lebih kecil dari 0,05 maka dapat dikatakan ada pengaruh antara kualitas jasa dengan loyalitas nasabah Upc Sawah Lebar. Kepercayaan $\left(X_{2}\right) t=2,444$ dengan nilai sig=0,021 maka dapat di simpulkan bahwa kepercayaan pengaruh terhadap Loyalitas nasabah. Untuk uji f dapat di simpulkan bahwasanya terdapat pengaruh secara bersama sama (simultan) antara kualitas jasa dan kepercayaan terhadap loyalitas nasabah di Upc Sawah Lebar dengan nilai f hitung 14,670 dan nilai p kurang dari 5 yakni 0,000.

\section{SARAN}

Berdasarkan hasil penelitian maka peneliti memberikan saran yang dapat dipertimbangkan berkaitan dengan hasil penelitian yakni: Kualitas jasa dan kepercayaan merupakan faktor penentu loyalitas nasabah, oleh karena itu diharapkan untuk meningkatkan lagi kualitas jasa, kepercayaan yang di berikan kepada nasabah agar dapat memperoleh tingkat loyalitas nasabah yang lebih baik lagi sehingga nasabah akan tetap loyal terhadap Pegadaian UPC Sawah Lebar. Hasil penelitian ini semoga bisa menjadi masukan kepada pihak upc untuk memberikan yang terbaik bagi nasabah nya.

\section{DAFTAR PUSTAKA}

Anugerah, Rizal. 2019. Pengaruh Kepuasan dan Kepercayaan Terhadap Loyalitas Pelanggan Jasa Pengiriman Barang JNE di Kota Palu. Jurnal Ilmu Manajemen Universitas Tadulako, Vol 5 No 2 p. 160-170.

Griffin, E. 2012. In A First Look at Communication Theory. Eight edition, New York: Mc.Grew Hill

Kennedy. 2002. Pediatric Operative Destistryy. Jakarta: EGC

Kotler, P., dan Keller, K. L.2012. Marketing Management. New Jersey: Pearson Prentice Hall

Mowen, John C dan Minor, Michael. 2002. Perilaku Konsumen. Jilid 1. Jakarta: PT Penerbit Erlangga

Priansah, Donni Juni. 2017. Prilaku Konsumen.Bandung : ALFABETA

Sinaga, Partua Pramana Hamonangan. 2010. Analisis Pengaruh Kualitas Pelayanan, Kepuasan Pelanggan, dan Lokasi Terhadap Loyalitas Pelanggan (Studi Kasus Pada Warnet Chamber Semarang). Universitas Diponegoro Semarang.

Sugiyono. 2013. Metode Penelitian Bisnis (Pendekatan Kuantitatif, Kualitatif, dan R\&D).

Cetakan Ke-17. Bandung : Alfabeta.

Tjiptono, Fandy. 2005. Pemasaran Jasa. Malang: Bayumedia Publishing.

Tjiptono, Fandy. 2000. Manajemen Jasa. Yogyakarta: Andi

Ulfa, Syafira. 2018. Pengaruh Kualitas pelayanan Terhadap Loyalitas Nasabah Dengan

Kepuasan Nasabah Sebagai Variabel Intervening (Studi Kasus Pada Bank Syariah Mandiri Petisah). Universitas Negeri Islam Sumatera Utara Medan.

38 I Ida Ayu Made Er M. G.; Eska P. M. D.; Pengaruh Kualitas Jasa dan Kepercayaan... 